\title{
PEMODELAN FAKTOR K BERBASIS RASTER SEBAGAI MASUKAN PEMODELAN EROSI DI DAS MERAWU, BANJARNEGARA, PROVINSI JAWA TENGAH (Modeling of Raster-Based of K Factor as Input for Erosion Modeling at Merawu Catchment, Banjarnegara, Central Java Province)
}

\author{
Bambang Sulistyo* \\ Fakultas Pertanian, Universitas Bengkulu, Jalan WR. Supratman, Kandang Limun, \\ Bengkulu 38371. \\ *Korespondensi. No Tel: 08136839 9675. Email: bambangsulistyounib@gmail.com.
}

Diterima: 8 Oktober 2014

Disetujui: 20 Maret 2015

\begin{abstract}
Abstrak
Penelitian ini bertujuan untuk mengkaji ketelitian absolut pemodelan faktor K berbasis raster sebagai masukan dalam pemodelan erosi Universal Soil Loss Equation (USLE) di Daerah Aliran Sungai (DAS) Merawu, Banjarnegara, Provinsi Jawa Tengah. Metode yang digunakan adalah dengan mengambil 30 sampel tanah secara stratified random sampling berdasarkan bentuk lahan DAS Merawu. Sampel tanah tersebut kemudian dianalisis di laboratorium sehingga diperoleh tekstur, permeabilitas, bahan organik, dan struktur yang diperlukan untuk menghitung faktor K menggunakan rumus yang sudah ada. Dari 30 sampel yang diambil, 24 sampel digunakan untuk menghitung faktor $\mathrm{K}$ dalam pemodelan, sedangkan 6 sampel lainnya digunakan sebagai uji model. Pengeplotan nilai K pada sampel di atas peta dilakukan sesuai dengan lokasi sampel, kemudian dilakukan digitasi dan rasterisasi dan dilakukan interpolasi spasial untuk memperoleh Peta K untuk setiap piksel dengan metode Kriging. Hasil pemodelan K tersebut $\left(\mathrm{K}_{\text {model }}\right)$ kemudian diuji pada 6 lokasi $\left(\mathrm{K}_{\text {aktual }}\right)$ untuk mengetahui ketelitian pemodelan. $\mathrm{K}_{\text {model }}$ dikatakan teliti jika memiliki nilai $\geq 80 \%$ terhadap $\mathrm{K}_{\mathrm{aktual}}$. Hasil penelitian menunjukkan bahwa pemodelan faktor K berbasis raster di DAS Merawu mempunyai ketelitian melebihi nilai ambang yang ditetapkan, yaitu sebesar 89,068\%, yang menunjukkan bahwa peta hasil pemodelan menggunakan analisis Kriging dapat digunakan untuk analisis lebih lanjut dalam menghitung erosi.
\end{abstract}

Kata kunci: erosi, faktor $K$, pengelolaan sumber daya alam, tanah kritis, daerah aliran sungai

\begin{abstract}
The research was aimed at knowing the absolute accuracy of modeling of raster-based $K$ factor as input for Universal Soil Loss Equation (USLE) erosion modeling at Merawu Catchment, Banjarnegara, Central Java Province. Methodology applied was by taking 30 soil samples of stratified random sampling based on landform of Merawu Catchment. Those 30 soil samples then were analised in a laboratory to get their texture, permeability, organic matter, and structure for $K$ factor computation using the existing formula. From 30 soil samples taken, 24 samples were used to model $K$ factor, while the other 6 soil samples were used for Model Validation. The result of computation for each sample then was plotted according to their position, digitized, transformed and spatially interpolated using Kriging technique to gain Map of $K$ factor of the study area $\left(K_{\text {model }}\right)$. $K_{\text {model }}$ then was validated with 6 soil samples of the $K_{\text {actual }}$ to know the accuracy of the model. $K_{\text {model }}$ is said to be accurate when its accuracy is $\geq 80 \%$ when compared to $K_{\text {actual }}$. The research result at Merawu Catchment showed that modeling of raster-based $K$ factor reached the accuracy of $\geq 80 \%$, that was $89.068 \%$, indicating that modeling of factor $K$ by using Kriging analysis can be used further for erosion analysis.
\end{abstract}

Keywords: critical soil, erosion, K factor, natural resources management, river catchment

\section{PENDAHULUAN}

Erosi tanah merupakan masalah lingkungan yang terjadi di berbagai belahan dunia yang berdampak negatif baik pada produksi pertanian, infrastruktur, kualitas air maupun biodiversitas (Arsyad, 2010; Hardjowigeno, 2007, Sulistyo, 2015). Di Indonesia, erosi tanah merupakan penyebab terjadinya tanah kritis yang jumlahnya dari tahun ke tahun mengalami peningkatan (Kartodihardjo, 2008). Perencanaan untuk melakukan rehabilitasi tanah kritis memerlukan data yang benar. Salah satu data yang diperlukan adalah adanya data erosi.

Pada umumnya, erosi diprediksi dari suatu model karena untuk memperoleh data erosi sesungguhnya memerlukan waktu, tenaga dan biaya yang tidak sedikit. Universal Soil Loss Equation (USLE) merupakan salah satu model prediksi erosi yang banyak digunakan di berbagai negara, termasuk di Indonesia. Bahkan Departemen Kehutanan telah sejak lama memberikan pedoman analisis erosi yang diberlakukan secara nasional dalam mengatasi lahan kritis (Anonim, 2009). 
Namun demikian, analisis erosi USLE dilakukan menggunakan data yang mempunyai model data vektor sehingga hasilnya mempunyai tingkat ketidakpastian (uncertainty) yang tinggi (Eweg dkk, 1998 dalam Sulistyo, 2011). DeMers (1997) menyatakan bahwa penyajian informasi kebumian dalam model data vektor mengasumsikan faktor homogenitas dalam suatu unit pemetaan atau kawasan. Suatu kawasan yang mempunyai sifat homogen dapat diperoleh dengan jalan klasifikasi dan penyederhanaan. Klasifikasi dan penyederhanaan inilah yang dilakukan secara subyektif sehingga kadang-kadang ditemui adanya penyederhanaan yang berlebihan (over simplification), sedemikian rupa sehingga variasi informasi kebumian yang sesungguhnya menjadi berkurang, bahkan hilang.

Pemodelan erosi USLE yang berbasis raster adalah pemodelan erosi yang semua data masukannya sudah dalam bentuk format raster. Dari 6 faktor erosi, yaitu R, K, L, S, C dan P, maka faktor LS, faktor $\mathrm{C}$ dan faktor $\mathrm{P}$ langsung dapat diperoleh format data yang berbasis raster menggunakan teknik Sistem Informasi Geografis (SIG). Faktor $\mathrm{R}$ dan faktor $\mathrm{K}$ dapat diperoleh format data yang berbasis raster dengan memanfaatkan interpolasi spasial yang ada dalam hampir semua piranti lunak SIG yang sudah ada (Chang, 2008). Hal ini sesuai dengan pendapat Fistikoglu dan Harmancioglu (2002) yang menyatakan bahwa erosi permukaan yang diestimasi menggunakan USLE akan lebih reliable apabila analisisnya menggunakan basis grid (raster) yang kecil dengan alasan bahwa USLE pada dasarnya dikembangkan pada kawasan sempit.

Erodibilitas tanah (faktor K) merupakan salah satu faktor penting dalam menentukan erosi model USLE (Pazhouhesh dkk, 2011). Namun demikian biasanya faktor $\mathrm{K}$ ditentukan secara sederhana, bahkan kadang-kadang hanya menggunakan asumsi-asumsi yang mendasarkan pada informasi jenis tanah (Anonim, 2009). Cara ini menghasilkan perkiraan nilai faktor $\mathrm{K}$ yang tidak teliti dan pada unit lahan yang sangat luas hanya diberikan satu nilai yang seragam. Bahkan jika tidak ada Peta Jenis Tanah maka Peta Geologi pun digunakan untuk memperkirakan nilai faktor $\mathrm{K}$, walaupun cara ini menghasilkan nilai faktor $\mathrm{K}$ yang tidak teliti (Karydas dkk, 2013).

Penentuan nilai faktor $\mathrm{K}$ berbasis raster pernah dilakukan oleh Bahrami dkk (2005) menggunakan sistem samar (fuzzy) terhadap 60 sampel tanah yang ditentukan berdasarkan nomograf Wischmeier. Hasilnya adalah bahwa nilai faktor $\mathrm{K}$ berkorelasi tinggi dengan nilai faktor $\mathrm{K}$ berdasarkan nomograf Wischmeier. Selanjutnya, pada tahun 2011, Pazhouhesh dkk (2011) juga melakukan penelitian sejenis dengan hasil yang sama. Sementara itu Assyakur (2008) menghitung prediksi erosi dengan menggunakan metode USLE dan SIG berbasis piksel di daerah tangkapan air Danau Buyan. Namun data masukannya belum semuanya berbasis piksel atau raster. Penelitian ini bertujuan untuk mengkaji ketelitian absolut dari pemodelan faktor $\mathrm{K}$ berbasis raster sebagai salah satu masukan dalam pemodelan erosi USLE di DAS Merawu, Kabupaten Banjarnegara, Provinsi Jawa Tengah.

\section{METODE PENELITIAN}

\section{Lokasi Penelitian}

Penelitian dilaksanakan di DAS Merawu yang merupakan sebagian dari daerah tangkapan Waduk Mrica yang berlokasi di Kabupaten Banjarnegara, Provinsi Jawa Tengah. Secara geografis, lokasi penelitian terletak pada koordinat 109 41 '24" $109^{\circ} 50^{\prime} 24^{\prime \prime}$ BT dan $7^{\circ} 10^{\prime} 12^{\prime \prime}$ - 7 ${ }^{\circ} 22^{\prime} 12^{\prime \prime}$ LS Daerah tangkapan Waduk Mrica umumnya bertopografi perbukitan dengan lembah yang curam. Sungai utama yang mengalir ke Waduk Mrica adalah Sungai Serayu dan Merawu. DAS Merawu menyumbang sedimen hasil erosi yang terbesar ke dalam Waduk Mrica sebagai salah satu Pembangkit Listrik Tenaga Air (PLTA).

\section{Data dan Program Yang Digunakan}

Dalam penelitian ini digunakan : Peta Topografi Skala 1:25.000; Peta Bentuk lahan hasil interpretasi Citra Satelit Landsat $7 \mathrm{ETM}^{+}$yang direkam pada tanggal 20 Juni 2006; Peta, buku, data dan laporan-laporan lain yang mendukung penelitian. Piranti lunak yang digunakan meliputi program SIG ILWIS (Integrated Land and Water Information System) versi 3.4., program SIG ARC/INFO versi 3.4.2., dan program SIG ARC/VIEW versi 3.3. Piranti keras yang digunakan meliputi seperangkat laptop dan komputer, seperangkat peralatan laboratorium/kantor yang meliputi meja digitizer dan alat gambar, peralatan lapangan yang terdiri dari teropong, kompas, belati, munsell soil colour book, palu geologi, ring sample, pita ukur, Global Positioning System (GPS), dan kamera digital.

\section{Penentuan nilai faktor $\mathrm{K}$ dan Pemetaannya}

Model prediksi erosi USLE dihitung dengan menggunakan persamaan sebagai berikut (Wischmeier dan Smith, 1978) :

$$
\mathrm{A}=\text { R.K.L.S.C.P }
$$

dalam hal ini :

$\mathrm{A}=$ jumlah tanah tererosi (ton/ha/tahun),

$\mathrm{R}=$ faktor erosivitas (curah hujan) $(\mathrm{MJ} / \mathrm{ha})(\mathrm{mm} /$ jam), 
$\mathrm{K}=$ faktor erodibilitas tanah (ton $\mathrm{x}$ ha $\mathrm{x}$ jam) / (ha $\mathrm{x}$ mega joule $\mathrm{x} \mathrm{mm}$ ),

$\mathrm{L}=$ faktor panjang lereng,

$\mathrm{S}=$ faktor kecuraman lereng,

$\mathrm{C}=$ faktor vegetasi penutup tanah dan pengelolaan tanaman,

$\mathrm{P}=$ faktor tindakan konservasi tanah.

Ukuran nilai $\mathrm{K}$ ditentukan oleh tekstur, struktur, permeabilitas, dan bahan organik tanah. Selanjutnya, penentuan nilai $\mathrm{K}$ dapat dilakukan dengan menggunakan rumus sebagai berikut :

$100 \mathrm{~K}=1,292[2,1 \mathrm{M} 1,14(10-4)(12-\mathrm{a})+$

$$
3,25(\mathrm{~b}-2)+2,5(\mathrm{c}-3)]
$$

dalam hal ini,

$\mathrm{M}=$ parameter ukuran butir yang diperoleh dari ( $\%$ debu $+\%$ pasir sangat halus) (100 - \% liat)

$\mathrm{a}=\%$ bahan organik $(\% \mathrm{c} \times 1,724)$

$\mathrm{b}=$ kode struktur tanah

$\mathrm{c}=$ kode kelas permeabilitas penampang tanah.

Penilaian struktur dan permeabilitas tanah masing-masing menggunakan Tabel 1 dan Tabel 2. Nilai faktor $\mathrm{K}$ dari sampel kemudian digunakan untuk memetakan nilai faktor $\mathrm{K}$ untuk keseluruhan DAS. Pemetaan nilai faktor K dari DAS dilakukan dengan cara melakukan interpolasi spasial yaitu proses menggunakan titik yang diketahui nilainya untuk mengestimasi nilai titik lain (Chang, 2008). Pada terapan SIG, interpolasi spasial diterapkan pada data raster dengan melakukan estimasi pada semua sel.

Interpolasi spasial mensyaratkan dua input dasar, yaitu titik yang diketahui serta teknik interpolasi. Titik yang diketahui (control points) merupakan titik-titik yang diketahui nilainya yang digunakan untuk membangun interpolator dalam interpolasi spasial. Jumlah dan penyebaran titik sangat mempengaruhi ketelitian interpolasi spasial. Asumsi dasar dalam interpolasi spasial yaitu bahwa nilai yang diestimasi pada suatu titik sangat dipengaruhi oleh titik-titik yang diketahui dan yang

Tabel 1. Penilaian struktur tanah.

\begin{tabular}{lc}
\hline \multicolumn{1}{c}{ Struktur } & Nilai \\
\hline Granular sangat halus & 1 \\
Granular halus & 2 \\
Granular kasar & 3 \\
Gumpal, lempeng, pejal & 4 \\
\hline \multicolumn{2}{l}{ (Sumber: Wischmeier dan Smith, 1978) }
\end{tabular}

Tabel 2. Nilai permeabilitas tanah.

\begin{tabular}{lcc}
\hline \multicolumn{1}{c}{ Kelas permeabilitas } & $\begin{array}{c}\text { Permeabilitas } \\
(\mathrm{cm} / \mathrm{jam})\end{array}$ & Nilai \\
\hline Cepat & $>12,7$ & 1 \\
Sedang sampai cepat & $6,3-12,7$ & 2 \\
Sedang & $2,0-6,3$ & 3 \\
Sedang sampai lambat & $0,5-2,0$ & 4 \\
Lambat & $0,125-0,5$ & 5 \\
Sangat lambat & $<0,125$ & 6 \\
\hline
\end{tabular}

(Sumber: Wischmeier dan Smith, 1978) letaknya lebih dekat daripada titik yang letaknya lebih jauh. Penyebaran titik-titik yang diketahui harus merata di seluruh lokasi kajian.

Ada beberapa teknik interpolasi yang dapat dipilih untuk mengestimasi titik yang tidak diketahui dari titik-titik yang diketahui, salah satu di antaranya adalah Kriging (Chang, 2008). Kriging merupakan teknik interpolasi yang memanfaatkan konsep geostatistik. Kriging mengasumsikan bahwa variasi keruangan dari atribut tidaklah acak secara keseluruhan (stokastik) demikian juga tidaklah deterministik. Akan tetapi, variasi keruangan terdiri dari tiga komponen yakni komponen yang berkorelasi secara spasial (yang menyajikan variasi dari veriabel secara regional), struktur (yang menyajikan trend), dan kesalahan acak. Kriging memanfaatkan semivariansi untuk mengukur komponen yang berkorelasi secara spasial, dan dirumuskan sebagai:

$\gamma(\mathrm{h})=(1 / 2)\left[\mathrm{z}\left(\mathrm{x}_{\mathrm{i}}\right)-\mathrm{z}\left(\mathrm{x}_{\mathrm{j}}\right)\right]^{2}$

di mana

$\gamma(\mathrm{h})=$ semivariansi antara titik-titik yang diketahui, $\mathrm{x}_{\mathrm{i}}$ dan $\mathrm{x}_{\mathrm{j}}$, yang dipisahkan oleh jarak $\mathrm{h}$;

$\mathrm{z}=$ nilai atribut.

Jika dalam data terdapat ketergantungan spasial dari titik-titik yang diketahui saling berdekatan akan mempunyai semivariansi yang kecil, demikian juga sebaliknya.

Untuk mengkaji variabilitas spasial dari fenomena yang dikaji diperlukan variogram yang menggambarkan hubungan antara semivariansi dengan rata-rata jarak, disebut semivariogram. Setelah itu semivariogram tersebut dapat digunakan untuk mengukur otokorelasi spasial data yang dianalisis. Namun demikian, untuk dapat digunakan sebagai interpolator dengan teknik Kriging maka semivariogram tersebut harus difitkan dengan fungsi matematis atau model. Kemudian variogram yang sudah fit tersebut dapat digunakan untuk mengestimasi semivariansi pada setiap jarak.

Semivariogram yang difitkan dapat dibagi menjadi tiga bagian yakni nugget, range, dan sill. Nugget merupakan semivariansi pada jarak $=0$, yang menunjukkan kesalahan pengukuran atau variasi yang sangat kecil, atau kedua-duanya. Range merupakan jarak di mana semivariansi mulai mendatar, yang menunjukkan bagian dari semivariogram yang berkorelasi secara spasial. Pada jarak di mana semivariansi mulai bernilai konstan disebut sill. Sill terdiri dari dua komponen yakni nugget dan partial sill, dengan kata lain, partial sill merupakan perbedaan antara sill dan nugget. Nilai-nilai nugget, range, dan sill inilah yang digunakan sebagai masukan dalam interpolasi spasial menggunakan teknik Kriging.

Persamaan umum yang digunakan untuk mengestimasi nilai $\mathbf{z}$ pada suatu titik adalah: 
$z_{0}=\sum_{i=1}^{s} z_{x} \cdot W_{x}$

di mana

$\mathrm{z}_{\mathrm{O}}=$ nilai yang diestimasi

$\mathrm{z}_{\mathrm{x}}=$ nilai yang diketahui pada titik $\mathrm{x}$

$\mathrm{W}_{\mathrm{x}}=$ bobot

$\mathrm{s}=$ jumlah titik sampel yang digunakan untuk melakukan estimasi.

Metode yang digunakan dalam penelitian ini adalah dengan mengambil 30 sampel tanah secara stratified random sampling berdasarkan bentuk lahan DAS Merawu. Penentuan lokasi pengambilan sampel tanah berdasar peta bentuk lahan ini sesuai dengan hasil kajian yang dilaporkan Clifford dan Valentine (2006) yang menyimpulkan bahwa interpolasi menggunakan Kriging akan lebih baik apabila menggunakan stratifikasi kewilayahan menggunakan peta bentuk lahan. Jumlah sampel 30 lokasi berdasarkan jumlah minimal untuk diuji kenormalannya (Sujana, 2002).

Sampel tanah tersebut kemudian dianalisis di laboratorium sehingga diperoleh tekstur, permeabilitas, bahan organik, dan struktur yang diperlukan untuk menghitung faktor $\mathrm{K}$ menggunakan rumus yang ada. Dari 30 sampel yang diambil, 24 sampel digunakan untuk menghitung faktor $\mathrm{K}$ dalam pemodelan, sedangkan 6 sampel lainnya digunakan sebagai penguji model.

Pengeplotan nilai $\mathrm{K}$ pada 24 sampel di atas peta dilakukan sesuai dengan lokasi sampel, kemudian dilakukan digitasi dan rasterisasi dan dilakukan interpolasi untuk memperoleh Peta K untuk setiap piksel dengan metode Kriging. Hasil pemodelan $\mathrm{K}$ tersebut $\left(\mathrm{K}_{\text {model }}\right)$ kemudian diuji pada 6 lokasi $\left(\mathrm{K}_{\mathrm{aktual}}\right)$ untuk mengetahui ketelitian pemodelan. $K_{\text {model }}$ dikatakan teliti jika memiliki nilai $\geq 80 \%$ terhadap $\mathrm{K}_{\mathrm{aktual}}$.

Dalam penelitian ini, ukuran tiap-tiap piksel yang dipilih adalah 30 meter x 30 meter sesuai dengan ukuran resolusi spasial Landsat $7 \mathrm{ETM}^{+}$ yang akan digunakan dalam menghitung erosi secara keseluruhan.

\section{HASIL DAN PEMBAHASAN}

Daftar nomor sampel dan nilai erodibilitasnya untuk setiap bentuk lahan disajikan pada Lampiran 1, sedangkan lokasi penyebaran sampelnya disajikan pada Gambar 1. Secara ringkas jumlah sampel untuk masing-masing bentuk lahan pada wilayah kajian disajikan pada Tabel 3 yang menunjukkan bahwa semakin luas bentuk lahannya maka semakin banyak jumlah sampel yang diambil. Hal ini sesuai dengan prinsip stratified random sampling.

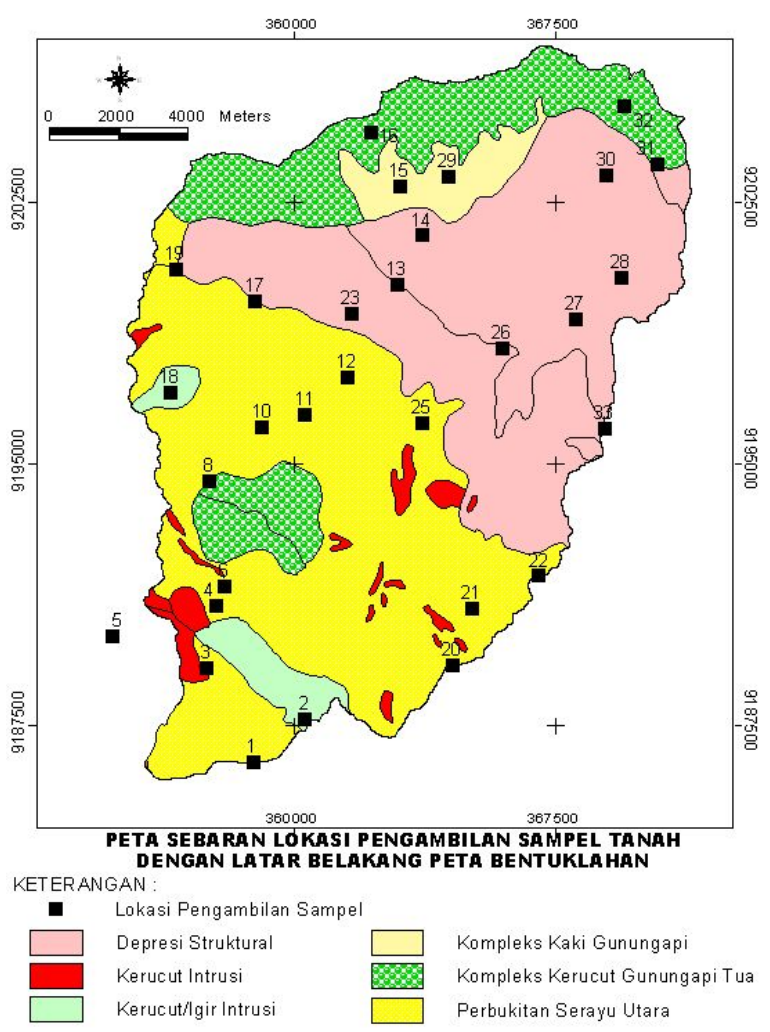

Gambar 1. Sebaran lokasi pengambilan sampel tanah.

Tabel 3. Jumlah sampel untuk masing-masing bentuk lahan pada wilayah kajian.

\begin{tabular}{lcc}
\hline \multicolumn{1}{c}{ Bentuk lahan } & Luas (Ha) & Jumlah sampel \\
\hline Perbukitan Serayu Utara & 8.932 & 10 \\
Depresi struktural & 8.013 & 9 \\
Kompleks kerucut & 3.615 & 4 \\
gunungapi tua & & \\
Kerucut intrusi & 867 & 3 \\
Kerucut/igir intrusi & 693 & 2 \\
Kompleks kaki gunungapi & 567 & 2 \\
\hline \multicolumn{2}{c}{ Jumlah sampel } & \\
\hline
\end{tabular}

Sebelum dilakukan analisis lebih lanjut, maka dilakukan uji normalitas untuk mengetahui apakah populasi berdistribusi normal atau tidak. Dalam penelitian ini uji normalitas data dilakukan menggunakan metode Kolmogorov Smirnov, dengan taraf signifikansi yang digunakan sebagai aturan untuk menerima atau menolak pengujian normalitas atau tidaknya suatu distribusi data adalah $\alpha=0,05$. Berdasarkan perhitungan normalitas diperoleh nilai $D_{\max }$, yaitu 0,114 . Dengan jumlah sampel yaitu 30 pada taraf

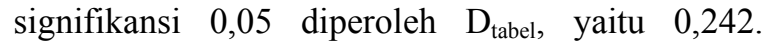
Populasi dikatakan berdistribusi normal jika $\mathrm{D}_{\text {hitung }}$ $<\mathrm{D}_{\text {tabel }}$. Hasil uji normalitas terhadap data yang digunakan dalam penelitian memperlihatkan bahwa data yang diperoleh dalam penelitian mempunyai 
bentuk distribusi yang normal sehingga memenuhi syarat untuk dianalisis lebih lanjut.

Hasil pemodelan faktor $\mathrm{K}$ yang berbasis raster disajikan pada Gambar 2. Hasil tersebut merupakan hasil setelah melakukan trial and error dalam penentuan sill, nugget dan range. Pemilihan sill, nugget dan range yang berbeda akan menghasilkan hasil pemodelan yang juga berbeda. Nilai sill, nugget dan range yang dipilih berturut-turut adalah 0,000; 0,013; dan 8.000.

Secara garis besar DAS Merawu mempunyai nilai rata-rata erodibilitas tanah sebesar 0,29, dengan nilai minimumnya 0,08 dan nilai maksimumnya 0,54 . Nilai erodibilitas tanah akan mempengaruhi terjadinya erosi secara linier, artinya dengan nilai erodibilitas tanah yang kecil akan menyebabkan terjadinya erosi yang kecil juga, demikian juga sebaliknya, jika nilai erodibilitas tanahnya besar maka akan menyebabkan terjadinya erosi yang besar juga.

Seperti telah disebutkan pada bagian terdahulu bahwa unit analisis dalam penilitian ini adalah pemetaan berbasis raster dengan ukuran tiap-tiap piksel yang dipilih adalah 30 meter x 30 meter (dengan demikian luas tiap piksel adalah $900 \mathrm{~m}^{2}$ ). Hal ini berarti untuk setiap kawasan dengan luas $900 \mathrm{~m}^{2}$ akan mempunyai nilai erodibilitas yang unique (tunggal) sebagai hasil dari interpolasi spasial. Dengan demikian untuk keseluruhan kawasan DAS Merawu akan diperoleh nilai erodibilitas yang sangat bervariasi. Hal ini juga yang dinyatakan oleh DeMers (1997) bahwa penyajian informasi kebumian dalam model data raster akan mempertahankan variasi informasi kebumian yang sesungguhnya, termasuk nilai erodibilitas.

Untuk keperluan pemetaan adalah tidak mungkin untuk menggambarkan legenda untuk masing-masing piksel yang memiliki nilai erodibilitas yang sangat bervariasi. Untuk itu diperlukan pengelompokan nilai erodibilitas untuk memudahkan pengguna peta untuk dapat membaca peta yang dihasilkan.

Dalam penelitian ini pengelompokan nilai erodibilitas dilakukan dengan cara memberi legenda yang berupa gradasi dari nilai erodibilitas yang terendah sampai dengan nilai erodibilitas yang tertinggi seperti yang disajikan pada Gambar 2 . Dari peta tersebut dapat dilihat bahwa hasil gradasi nilai erodibilitas memberikan gambaran pola seperti halnya garis kontur yang menghubungkan nilai erodibilitas yang gradasinya hampir sama. Pola garis-garis kontur nilai erodibilitas tersebut bahkan ada yang membulat pada beberapa kawasan, yaitu di sebelah Barat (di Kecamatan Karangkobar) dan di bagian tengah (di perbatasan Kecamatan Karangkobar dan Kecamatan Wanayasa) dan di

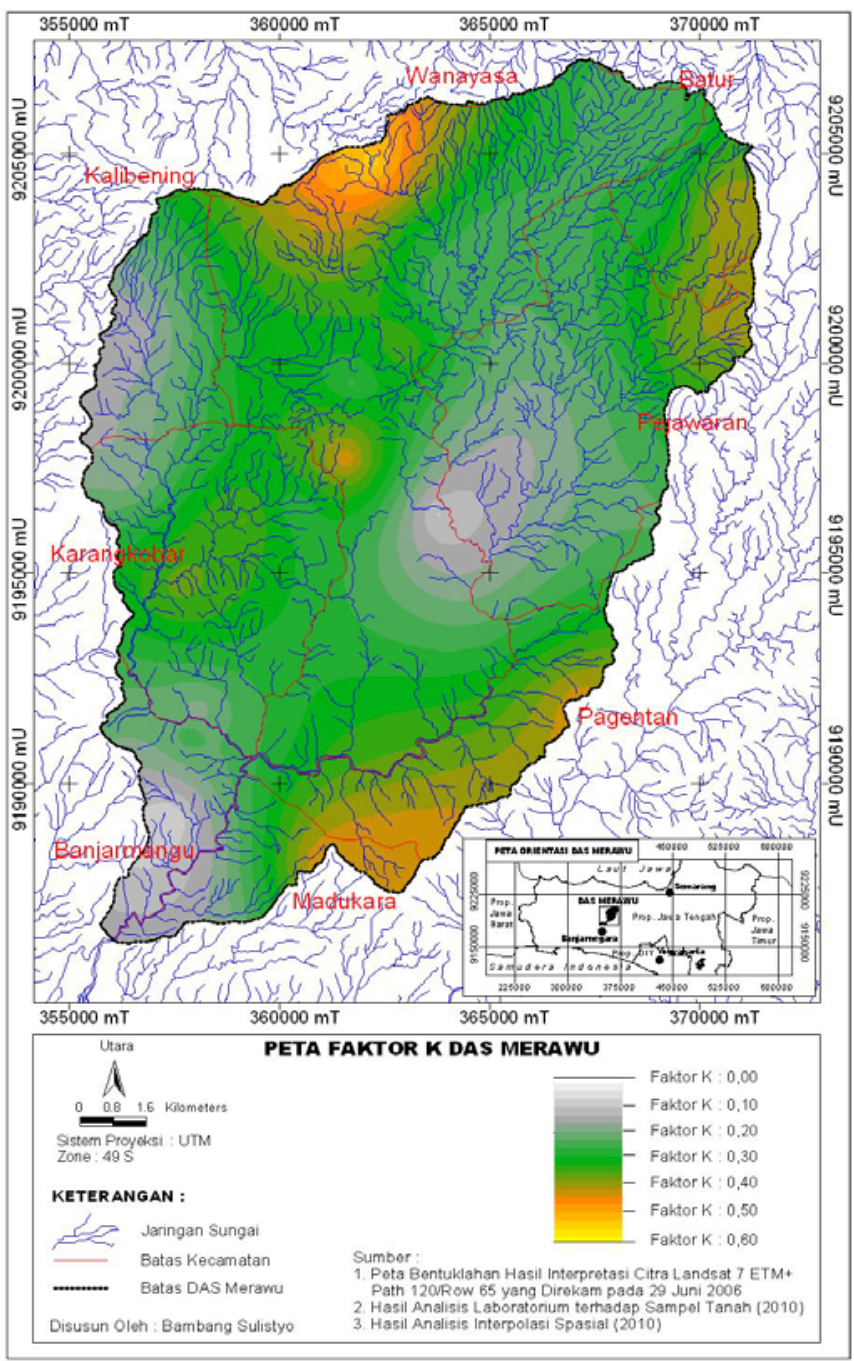

Gambar 2. Peta faktor K DAS Merawu.

bagian Timur (di perbatasan Kecamatan Wanayasa dan Kecamatan Pejawaran). Pola-pola tersebut merupakan hasil murni dari interpolasi spasial dengan metode Kriging yang dipilih dalam penelitian ini. Pola yang berbeda tentunya akan dihasilkan apabila dipilih teknik interpolasi spasial yang berbeda.

Sebagai sebuah model maka diperlukan suatu validasi model dengan cara melakukan Pembandingan antara faktor $\mathrm{K}$ hasil pemodelan $\left(\mathrm{K}_{\text {model }}\right)$ dengan faktor $\mathrm{K}$ aktual $\left(\mathrm{K}_{\mathrm{aktual}}\right)$. Enam titik dipilih sebagai lokasi pengukuran faktor $\mathrm{K}$ yang digunakan sebagai uji/validasi model. Koordinat dari masing-masing lokasi disajikan sebagai peta titik. Peta titik ini kemudian ditumpangsusunkan di atas peta faktor $\mathrm{K}$ hasil pemodelan. Hasil analisis pembandingan antara $\mathrm{K}_{\text {model }}$ dengan $\mathrm{K}_{\text {aktual }}$ disajikan pada Tabel 4.

Dari Tabel 4 dapat diketahui bahwa Ketelitian Peta Erodibilitas Tanah yang diperoleh yaitu sebesar $89,068 \%$ yang menunjukkan bahwa peta hasil pemodelan menggunakan analisis Kriging 
Tabel 4. Hasil pengecekan nilai erodibilitas (K).

\begin{tabular}{ccccc}
\hline Nomor Nilai erodibilitas dari hasil & Selisih & \multicolumn{1}{l}{$\begin{array}{l}\text { Ketelitian } \\
(\%)\end{array}$} \\
\cline { 2 - 4 } Pengecekan & $\begin{array}{c}\text { Pemodelan - } \\
\text { analisis } \\
\text { Kriging }\end{array}$ & & \\
\hline 4 & 0,2442 & 0,1989 & 0,0453 & 79,550 \\
15 & 0,3001 & 0,3382 & 0,0381 & 88,061 \\
17 & 0,2862 & 0,2672 & 0,0190 & 93,128 \\
21 & 0,3585 & 0,3731 & 0,0146 & 96,003 \\
27 & 0,2424 & 0,2647 & 0,0223 & 91,203 \\
30 & 0,2842 & 0,3255 & 0,0413 & 86,461 \\
\hline \multicolumn{5}{c}{ Ketelitian peta rata-rata $=89,068 \%$} \\
\hline
\end{tabular}

dapat digunakan untuk analisis lebih lanjut dalam menghitung erosi. Hasil penelitian ini menunjukkan bahwa setiap pergeseran 30 meter ke arah Timur, Selatan, Barat atau Utara maka sudah dapat diketahui nilai faktor K-nya tanpa harus mengukur secara langsung di lapangan. Jika Bahrami dkk (2005) dan Pazhouhesh dkk (2011) sudah menyimpulkan bahwa secara statistik bahwa penentuan faktor $\mathrm{K}$ melalui model tersebut berkorelasi tinggi dengan faktor $\mathrm{K}$ sesungguhnya, maka pada penelitian ini ditunjukkan hasil perbandingannya dalam bentuk ketelitian absolutnya.

\section{KESIMPULAN}

Pemodelan faktor $\mathrm{K}$ berbasis raster di DAS Merawu menunjukkan bahwa Ketelitian Peta Erodibilitas Tanah yang diperoleh melebihi nilai ambang yang ditetapkan, yaitu sebesar $89,068 \%$, yang menunjukkan bahwa peta hasil pemodelan menggunakan analisis Kriging dapat digunakan untuk analisis lebih lanjut dalam menghitung erosi.

\section{DAFTAR PUSTAKA}

Anonim, 2009. Peraturan Menteri Kehutanan RI Nomor : P. 32/Menhut-II/2009 tentang Tata Cara Penyusunan Rencana Teknik Rehabilitasi Hutan dan Lahan Daerah Aliran Sungai (RTkRHL-DAS). Jakarta.

Arsyad, S., 2010. Konservasi Tanah dan Air. Edisi kedua. IPB Press. Bogor.

As-syakur, A.R., 2008. Prediksi Erosi dengan Menggunakan Metode USLE dan Sistem Informasi Geografis (SIG) Berbasis Piksel di Daerah Tangkapan Air Danau Buyan. Pusat Penelitian Lingkungan Hidup Universitas Udayana. Denpasar.

Bahrami, H.A., Vaghei, H.G., Vaghei, B.G., Tahmasbipour, N., dan Taliey-Tabari, F., 2005. A New Method for Determining The
Soil Erodibility Factor based on Fuzzy Systems. Journal of Agriculture Science Technology, 7:115-123.

Chang, K.T., 2008, Introduction to Geographic Information Systems, McGraw-Hill International Edition, New York.

Clifford, N., dan Valentine, G., 2006. Key Methods in Geography, SAGE Publications, London.

DeMers, M.N., 1997. Fundamental of Geographic Information Systems, John Wiley \& Sons, New York.

Fistikoglu, O., dan Harmancioglu, N.B., 2002. Integration of GIS with USLE in Assessment of Soil Erosion, Water Resources Management, 16:57-68.

Hardjowigeno, S., 2007. Ilmu Tanah. Edisi baru. Jakarta. Akademika Pressindo.

Kartodihardjo, H., 2008. Pengelolaan Sumberdaya Alam dan Lingkungan Hidup, Seminar Lingkungan Hidup dan Sumberdaya Alam, Universitas Bengkulu, Bengkulu; 20 April 2008.

Karydas, C.G., Petriolis, M., dan Manakos, I., 2013. Evaluating Alternative Methods of Soil Erodibility Mapping in the Mediterranean Island of Crete, Agriculture, 3:362-380.

Pazhouhesh, M., Gorji, M., Taheri, S.M., dan Keshavarzi, A., 2011. Determination of Soil Erodibility Factor Using Fuzzy Rule Base System, International Journal of Environmental Sciences, 1(7):1874-1883.

Sudjana, 2002. Metoda Statistika, Penerbit Tarsito, Bandung.

Sulistyo, B., 2011. Pemodelan Spasial Lahan Kritis Berbasis Raster di DAS Merawu Kabupaten Banjarnegara Melalui Integrasi Citra Landsat $7 \mathrm{ETM}^{+}$dan Sistem Informasi Geografis, Disertasi. Program Pascasarjana Fakultas Geografi, Universitas Gadjah Mada. Yogyakarta.

Sulistyo, B., 2015. Kajian Perubahan Tingkat Kekritisan Lahan Sebagai Akibat Proses Eliminasi Unit Lahan (Studi Kasus Di Kawasan Pertambangan Danau Mas Hitam, Provinsi Bengkulu). Seminar Nasional Masyarakat Biodiversitas Indonesia. Universitas Gadjah Mada. Yogyakarta, 21 Maret 2015.

Wischmeier, W.H., dan Smith, D.D., 1978. Predicting Rainfall Erosion Losses : A Guide to Conservation Planning. Science and Education Administration USDA in cooperation with Purdue Agriculture Experiment Station, Purdue. 
Lampiran 1. Daftar nomor sampel, nilai erodibilitasnya untuk setiap bentuk lahan.

\begin{tabular}{|c|c|c|c|}
\hline No. & Bentuk lahan & Jenis tanah & Erodibilitas \\
\hline 1 & Perbukitan Serayu utara & Asosiasi latosol cokelat dan regosol kelabu & 0,193 \\
\hline 2 & Kerucut/igir intrusi & Kompleks grumusol, regosol dan mediteran & 0,434 \\
\hline 3 & Kerucut intrusi & Kompleks grumusol, regosol dan mediteran & 0,079 \\
\hline 4 & Kerucut intrusi & Kompleks grumusol, regosol dan mediteran & 0,244 \\
\hline 5 & Kerucut intrusi & Litosol & 0,185 \\
\hline 6 & Perbukitan Serayu utara & Kompleks grumusol, regosol dan mediteran & 0,176 \\
\hline 8 & $\begin{array}{l}\text { Kompleks kerucut gunungapi } \\
\text { tua }\end{array}$ & Kompleks grumusol, regosol dan mediteran & 0,360 \\
\hline 10 & Perbukitan Serayu utara & Latosol cokelat & 0,347 \\
\hline 11 & Perbukitan Serayu utara & Latosol cokelat & 0,260 \\
\hline 12 & Perbukitan Serayu utara & Latosol cokelat & 0,429 \\
\hline 13 & Depresi struktural & Asosiasi andosol cokelat dan regosol cokelat & 0,342 \\
\hline 14 & Depresi struktural & Asosiasi andosol cokelat dan regosol cokelat & 0,234 \\
\hline 15 & Kompleks kaki gunungapi & Asosiasi andosol cokelat dan regosol cokelat & 0,300 \\
\hline 16 & $\begin{array}{l}\text { Kompleks kerucut gunungapi } \\
\text { tua }\end{array}$ & Asosiasi latosol cokelat dan regosol kelabu & 0,536 \\
\hline 17 & Depresi struktural & Asosiasi andosol cokelat dan regosol cokelat & 0,286 \\
\hline 18 & Kerucut/igir intrusi & Asosiasi latosol cokelat dan regosol kelabu & 0,176 \\
\hline 19 & Perbukitan Serayu utara & Asosiasi latosol cokelat dan regosol kelabu & 0,147 \\
\hline 20 & Perbukitan Serayu utara & Asosiasi latosol cokelat dan regosol kelabu & 0,403 \\
\hline 21 & Perbukitan Serayu utara & Asosiasi latosol cokelat dan regosol kelabu & 0,359 \\
\hline 22 & Perbukitan Serayu utara & Asosiasi latosol cokelat dan regosol kelabu & 0,430 \\
\hline 23 & Depresi struktural & Asosiasi andosol cokelat dan regosol cokelat & 0,249 \\
\hline 25 & Perbukitan Serayu utara & Latosol cokelat & 0,103 \\
\hline 26 & Depresi struktural & Asosiasi andosol cokelat dan regosol cokelat & 0,172 \\
\hline 27 & Depresi struktural & Asosiasi andosol cokelat dan regosol cokelat & 0,242 \\
\hline 28 & Depresi struktural & Asosiasi andosol cokelat dan regosol cokelat & 0,362 \\
\hline 29 & Kompleks kaki gunungapi & Asosiasi andosol cokelat dan regosol cokelat & 0,259 \\
\hline 30 & Depresi struktural & Asosiasi andosol cokelat dan regosol cokelat & 0,284 \\
\hline 31 & $\begin{array}{l}\text { Kompleks kerucut gunungapi } \\
\text { tua }\end{array}$ & Asosiasi glei humus dan aluvial kelabu & 0,401 \\
\hline 32 & $\begin{array}{l}\text { Kompleks kerucut gunungapi } \\
\text { tua }\end{array}$ & Asosiasi andosol cokelat dan regosol cokelat & 0,252 \\
\hline 33 & Depresi struktural & Asosiasi andosol cokelat dan regosol cokelat & 0,222 \\
\hline
\end{tabular}

